Author running head: Nicholas A. Phelps and Holi Bina Wijaya

Short title running head: Growth and constraints in industry clusters

\title{
Growth and growth constraints in craft industry clusters: The batik industries of Central Java
}

\author{
Nicholas A. Phelps and Holi Bina Wijaya ${ }^{2}$ \\ ${ }^{1}$ Faculty of Architecture, Building and Planning, University of Melbourne, Melbourne, Victoria \\ ${ }^{2}$ Urban and Regional Planning Department, Diponegoro University, Semarang
}

\begin{abstract}
We investigate the constraints on and forms of business change and how these shape collective dynamics in batik-producing districts in Indonesia. Conceptually, this paper argues the need to incorporate insights regarding the constraints on, forms of change and segmentation of small businesses with those relating to the collective dynamics of industry agglomerations and the possibilities for policy to effect joint action. We examined 89 batik businesses surveyed across four districts in Surakarta and Pekalongan, Central Java. Overall, the picture we find is one of constraint, modest forms of change and weariness of the effects that policy can have on collective dynamics. In the face of much diminished batik industry agglomerations in both cities, we find little evidence of differences in growth patterns and constraints according to location or industry segment.
\end{abstract}

Keywords: Industry clusters, joint action, segmentation, batik industry, Indonesia

This is the author manuscript accepted for publication and has undergone full peer review but has not been through the copyediting, typesetting, pagination and proofreading process, which may lead to differences between this version and the Version of Record. Please cite this article as doi: $10.1111 /$ sjtg.12311

This article is protected by copyright. All rights reserved. 
Accepted: 10 September 2019

\section{Introduction}

The theory of agglomeration (or clustering) based on the concept of external economies contains elements of analytical circularity (Phelps, 1992) arising from ambiguities regarding the relationship between individual and collective businesses dynamics. These elements of analytical circularity have significant implications for comparisons made between what Gordon and McCann (2000) term the social network form of agglomeration found in developed countries and craft industry clusters prevalent in developing countries (Weijland, 1999) and for policy prescriptions (on, for example, joint action) in support of agglomeration (Schmitz, 1995, 1999) in developing countries. Both the comparison and the efficacy of the policy prescription may be overdrawn. It appears that individual business and collective dynamics in many industries in many developing countries result in stasis in industry agglomerations. With a view to understanding some of the possible reasons for this, we pose the following questions:

1) What are the growth dynamics and forms of growth pursued by businesses?

2) What are the constraints on growth facing individual businesses?

3) How might these present limits on the possibilities for policies to support craft industry clusters, mobilizing localized external economies by way of joint action (Schmitz, 1999)? 
Conceptually, this paper argues the need to reconcile insights regarding the dynamics of individual businesses and the collective dynamics of industry agglomerations in an appreciation of the potentials of industry agglomerations and policy to support them. This entails: a need to re-incorporate insights regarding small firm growth constraints in the developing world (Schmitz, 1982)—acknowledged prior to, and overshadowed by, an interest in the collective dynamics of agglomerations (Schmitz, 1995, 1999), and; a need to newly incorporate literature speaking to the developed world identifying constraints on, and forms of, small business growth (ACOST, 1990; O’Farrell \& Hitchens, 1988; Turok, 1989). In conclusion, we suggest that segmentation is sufficiently common to developed and developing country settings (Nichter \& Goldmark, 2009; Taylor \& Thrift, 1982) to offer a possible conceptual means to reconcile an appreciation of these interactions of business dynamics at the individual and collective levels.

Empirically, we draw upon a study covering 89 businesses in the traditional craft industry of batik in two districts in each of the cities of Surakarta and Pekalongan in Indonesia. The research strategy was designed to explore patterns of business growth, growth constraints and aspects of industry organization (notably subcontracting relations) at the intra- and inter-urban scales while also seeking to understand how these related to significant policy support for joint action (though this term did not explicitly inform the policies concerned). We were also able to explore whether segmentation of batik industry agglomerations into small and medium-scale producers had a bearing on growth dynamics, forms of growth, constraints on growth and the effects of policy. Despite a priori reasons to expect some contrasts in these two respects, the 
picture that arises from our study is one of uniformity across the industry regardless of location and segment.

The paper begins by discussing some of the limits of existing theories contributing to an understanding of firm and collective dynamics in industry agglomerations in developing countries. We then recount the methods used in a survey of batik producers in Surakarta and Pekalongan before going on to present our research findings. We conclude by stressing the need to further consider how the nature of industry development in developing countries translates into: particular business aspirations and forms of growth; particular relationships between these business dynamics and the constraints on business development associated with them, on the one hand, and the presence of external economies and potential for joint action, on the other hand.

\section{Between individual and collective dynamics in craft industry clusters}

Insights from literature on small firm growth constraints and forms of growth suggest the need to weigh the dynamics of individual businesses against the collective dynamics of industry agglomerations in the prospects for local economic development. We illustrate these ideas with reference to research on entrepreneurship in Indonesia.

Growth and constraints on business growth

Business growth in the small firm sector cannot be assumed. The literature on small firm growth constraints alerts us to this feature of the small (formal and informal) firm sector in developed and developing countries alike. In the case of primarily formal businesses of developed 
countries, the growth motivation of the majority of entrepreneurs is one of wanting to maintain the status quo (Davidsson, 1991), while a significant minority of small business owners in such settings do not wish to grow or simply wish to maintain their business (SBRC, 1992). Even in developed country settings, the implications of this finding have tended to be underplayed (O’Farrell \& Hitchens, 1988) despite evidence that only a tiny minority of all businesses grow to any significant size from the churn in stocks of small businesses (Storey, 1994). In the developed country setting there has been some recognition that a proportion of entrepreneurial aspirations reflect a desire simply to pass on the business to family members (ACOST, 1990) and even that not only do many small manufacturing companies not have the resources to grow but also lack the inclination and the expertise (O'Farrell \& Hitchens, 1988: 1375). Set alongside earlier critiques of assumptions regarding the lack of capabilities and aptitudes of entrepreneurs from developing countries (Schmitz, 1982), what this literature reminds us is that for a portion of all businesses in developed and developing countries alike, the constraints on growth are as much internal as they are external to the firm.

The literature relating to the developed world has been particularly strong on questioning the direction of causality between internal and external constraints on firm growth and by extension the relationship between processes internal to the firm and external to it in an agglomeration (ACOST, 1990; O'Farrell \& Hitchens, 1988). This is certainly the case in Indonesia (JICA, 2004) where the broad contours of one early interpretation of entrepreneurship highlighted how industry was characterized by 'wide differences in business expertise and 
managerial sophistication and by the obtrusion into the operations of enterprise of all manner of subjective, culturally conditioned considerations that impede maximum efficiency' and a lack of historic and cultural continuity or acceptance surrounding entrepreneurs and entrepreneurship (Van der Kroef, 1960: 419 and 416 respectively). Recent evidence suggests that some of the contextual constraints on perceptions of entrepreneurship have loosened greatly in Indonesia (Nawangpalupi et al., 2014). However, slow, inter-generational, processes of change remain apparent in the developing country setting as part of a complex of reasons that militate against the dominance of strategies of aggressive accumulation associated with modern industry sectors. The same survey of entrepreneurship in Indonesia noted the extremely low and declining proportion of entrepreneurs who perceived themselves as playing an 'active and leading' role in innovation processes in Indonesia (Nawangpalupi et al., 2014: 40-41).

Such non-growth aspirations may have wider repercussions in that sources of innovation from within the firm may be less, given socio-cultural views of the inappropriateness of employees showing initiative and from outside of the firm given that inter-firm linkages and networks may be a source predominantly of imitation and survival rather than product or process innovation (Turner, 2003: 153). Indeed, 'small-scale entrepreneurs in developing countries may well be operating in a contextual environment in which economic ideas of profit and loss are not the only markers of "success" ... this certainly does not sit well with the concept of "growth"” (Turner, 2003: 37) and Turner's (2003) research on small firms in Makassar is particularly 
revealing of the sorts of factors that lead in the direction of entrepreneurial strategies that involve survival or subsistence as opposed to consolidation or accumulation.

\section{Forms of business change}

A diverse literature focuses on the form that business change takes. Massey and Meegan (1983) adopted a structuralist approach to accounting for job loss in the UK. Their concern was with employment loss in large firms and they distinguished technical change, rationalization and intensification as three forms of change, highlighting the importance of the latter-associated with piecemeal changes in process technology and work practices. Their work was adapted by Turok (1989) who also drew on the small business literature to incorporate other potential forms of change. Several different forms of business change were enumerated in a study of small firm business change in Southwark, London and, in modified form, constitute the basis for part of the empirical analysis of this paper: (a) extensive growth - the addition of more of the same capacity; (b) rationalization — the cutting of capacity; (c) intensification—-the piecemeal adoption of new process technology; (d) product development: the development of new products; (e) technical change—substantial investment in process technology; (f) stagnation—no change in either process or product technology; and (g) diversification. Turok’s study of small companies revealed that business change took a variety of forms often involving 'non-ambitious entrepreneurship' (Bosma \& Schutjens, 2009). This conclusion is important, since assumptions regarding the nature of innovation and business change in some of the literature on industry 
agglomeration in developing countries jars with the realities of entrepreneurship found in developed let alone developing countries. ${ }^{1}$

Particular forms of change are likely to be prevalent in the developing country setting. Notably, stagnation, extensive and intensive forms of growth rather than the likes of product development, and technological change are likely to predominate in many developing country settings. Product development as a form of change in industry agglomerations in developing countries is likely to be limited as this form of growth is extremely stressful for small businesses (Oakey, 1983). A report on the Sukoharjo furniture industry (GTZ, 2008: 20) highlighted the innovation in design which was apparent amounted to little more than the copying from international catalogues with resultant limited value added. Imitation and copying are the essential mode of business development in many traditional industry agglomerations while 'innovation may be especially difficult to achieve if a small enterprise has found a certain marketing niche. For these enterprises, it is tempting to remain there rather than try to compete in another market' (Turner, 2003: 54). The problems are particularly serious for the small business in developing countries 'when discontinuous leaps of investments are required for the expansion of craft industry beyond its family resources (Grosh \& Somolekae, 1996: 1881 cited Weijland 1999: 1515-6). Notwithstanding the limits of equating traditional industries with stagnation and modern industry sectors with economic dynamism (McGee, 1974), many traditional industry agglomerations in Indonesia have remained fairly stagnant (JICA, 2004; Weijland, 1999). Some indication of the inertia involved in developing country settings is provided by Turner's study of small firms in 
Makassar where over half of the businesses reported no change in their technology being used and as many as 65 per cent of entrepreneurs had made no change to methods of production. Craft industries in Indonesia were seen as remarkably passive with regard to the development of skills, product ranges, marketing, and the raising of capital, with businesses often waiting for buyers to come to their door-though this did not prevent export success (UNDP et al., 1988: 146 cited Weijland 1999: 1516). Many of these craft clusters consist of very small enterprises that produce for very local markets (JICA, 2004) relying substantially on unpaid family workers and incidental use of paid labourers. These micro-enterprise agglomerations were frequently found to evidence very little change in technology and markets (Sandee et al., 2002).

\section{Business segmentation and industry agglomeration}

Segmentation is a feature that may affect growth and growth constraints of individual businesses and their collective dynamics. A focus on the diversity of growth aspirations and forms of business change pursued is also important therefore in drawing attention to the manner in which industry clusters are effectively segmented both in developed (Taylor \& Thrift, 1982) and developing country economies (Nichter \& Goldmark, 2009). For the informal enterprises that predominate in developing countries to be able to capture important external economy effects, 'the relationships between formal and informal enterprises along the value chain must be symmetrical and non-hierarchical' (Moreno-Monroy, 2012: 2024). This has led Moreno-Monroy (2012) and Nichter and Goldmark (2009) to suggest that policy ought to recognize the

prevalence of business segmentation. Segmentation does appear important to understanding 
some of the failures of cluster development policies to stimulate internal and external networking (Tambunan, 2005) and joint action (Phelps \& Wijaya, 2016) among firms.

The batik industry—which is the subject of the empirical results reported later in this paper—has a measure of such segmentation. In the broadest terms there is segmentation between the significantly domestically-oriented craft industry that is batik and the larger, modern factory and export-based textile and clothing industry that has grown significantly as a result of foreign direct investment (FDI) (Dicken \& Hassler, 2000). The two sectors are largely separate including in their geographic locations (the former being concentrated significantly in Central Java) the latter in West Java and greater Jakarta in particular). Within the batik industry, there is further segmentation between a handful of large vertically integrated mass producers (such as Batik Danar Hadi, Batik Keris and Batik Semar) which are vertically integrated and continue to employ canting and cap techniques alongside printing and which might be considered to span the export and domestic textile-clothing sectors noted above; larger city-based producers and marketers of batik (or juragan) and merchants (or saudagar) who commonly also now produce directly or indirectly; bakul traders who collect batik products from batik artisans and sell it to the market and who commonly also become suppliers to shops and/or saudagar producers, and; a very large number of individual outworkers scattered into the rural hinterlands of cities. The bakul traders in particular, often are more risk averse given the lack of distinction between family and business-related expenditures and incomes but are also more collectively-oriented at the level of neighbourhood and extended family and friendship networks (Wijaya, 2009). The 
juragan and saudagar have a greater focus on their individual business and typically operate on a more contractual basis but also present a more mixed picture regarding aspirations and growth prospects. Moreover, the distinction between juragan and saudagar have diminished over time to the point that we do not distinguish between them in our analysis. There is, for example, a difference between the optimism of newer generations compared to old and important obligations beyond the business governed by Javanese cultural values which link wealth and social prestige to wider social obligations (Wijaya, 2009: 105).

\section{Public policy and craft industry clusters}

The geographic agglomeration of business and the competitive success of such agglomerations have traditionally been explained with reference to the concept of external economies; those benefits that are external to an individual enterprise shared across a large number of businesses. The Marshallian externalities of labour market pooling, reduced costs associated with interfirm linkages and localized knowledge flows that make up the 'industrial atmosphere' drive collective efficiencies. However, influential accounts (Schmitz, 1995, 1999) highlight how these Marshallian processes of agglomeration cannot be assumed in developing countries. Rather, external economies often remain latent and have to be mobilized instead by deliberate 'joint action'. Joint action can take one of two forms. It can be horizontal, resulting from individual businesses self-organizing informally (by sharing equipment, for example) or formally (in the creation of consortia or associations). It can also be vertical—that is, led by leading individual businesses or deliberately encouraged by way of public policy. Joint action is needed if 
agglomerations of businesses in developing countries are to adapt to new competitive pressures notably by reducing the technological leaps that individual businesses are often required to make (Nadvi, 1999) and, more often than not, horizontal and vertical actions of businesses are in need of reinforcement from public policy.

Subsequent studies have gone further still in highlighting the difficulties facing agglomerations of businesses in developing countries. Urban agglomeration may represent no real opportunity in particular (Perry, 2005: 231) because it is far from clear whether the largely informal industry clusters found in developing country settings can capture external economy effects (Moreno-Monroy, 2012). The latency of external economies in developing country industry clusters cannot be assumed in a situation where many are composed of fluctuating numbers of enterprises whose mode of operation is survival (Altenburg \& Meyer-Stamer, 1999). Heroic or 'ambitious' (Bosma \& Schutjens, 2009) entrepreneurial processes that have underlain the growth of significant agglomerations and indeed the theory of agglomeration in developed countries cannot be assumed. Instead 'joint action is often disrupted by a set of diseconomies emerging from informal production, including pernicious forms of informal competition, the informal institutional context and the opportunistic behaviour emerging within and around the industry’ (Harris, 2016: 318).

Integrating insights from literature on the growth constraints, growth aspirations and segmentation of businesses with literature on the potential of public policy in support of joint action leads to several departure points for the empirical analysis that follows. First, the shifting 
boundaries of the firm raises issues regarding: the relationship between processes of internalization and externalization (Phelps, 1992) and hence the significance of internal versus external constraints on business growth, and, as a consequence; the efficacy of public policies and institutions seeking to mobilize joint action. Qualitatively different forms of change sought by individual businesses provide some indirect indication of those constraints internal to individual businesses and are also likely to have a bearing on the efficacy of public policies aimed to unlock these collective efficiencies. Finally, industry agglomerations may be divided into more or less distinct segments and this may have implications for the growth constraints, entrepreneurial aspirations and the efficacy of public policy to support industry agglomerations.

\section{Research methods}

This research focuses on the growth dynamics, forms of business change, constraints on growth and the effects of policy on batik businesses agglomerated into two districts in each of Surakarta and Pekalongan in Central Java as well as the perceived constraints on business development (Figure 1). These two cities have been the main centres of batik production in Indonesia. They have contrasting histories in the emergence of perhaps Indonesia's most famous craft. External economies and joint action that may drive their development are commonly held to be placespecific. The research design therefore enabled intra- and inter-urban variations in the growth dynamics of individual businesses to be examined. However, we are also able to explore whether the experiences of localized batik businesses in this regard reflect their segmentation into smalland medium-scale producers. 
In each of the four districts (Kauman and Laweyan in Surakarta and Kauman and Pesindon in Pekalongan) we sought to survey all businesses involved directly or indirectly with production using a standard 4 page questionnaire form. ${ }^{2}$ As has been common practice with other empirical studies of industry agglomerations, the surveys sought to elicit information not only about aspirations for and constraints on business growth and forms of business change pursued but also: the age and origin of the businesses; the activities undertaken on-site, and; the geographical organization of production activities. Surveys were carried out in Surakarta in November 2014 and in Pekalongan in January 2015. Access to businesses was negotiated through industry leaders in order for the majority of the businesses to be surveyed face-to-face. Access was considered important due to 'survey fatigue'-notably in Surakarta which had become something of a model city within Indonesia by the time of our research (Phelps et al. 2014) and the relatively closed nature of some of the batik communities themselves. ${ }^{3}$ Face-toface meetings typically lasted 30 to 60 minutes and were a rich source of quantitative and qualitative information. A number of questionnaires were also distributed by industry leaders or a trusted aide. We have no reason to believe that these responses were biased in any important way when compared to those obtained face-to-face: there is no evidence that they elicited factual information that was more limited than those conducted face-to-face or were completed in less time than the lower-end 30 minutes duration achieved with those questionnaires administered face-to-face. 
In addition, we garnered views from eight interviews with industry representatives (such as leaders of industry clusters and cooperative organizations such as Gabungan Koperasi Batik Indonesia (GKBI) ${ }^{4}$, local government departments and three large multi-site batik companies. Together with the additional notes made while conducting face-to-face questionnaire surveys with the majority of individual businesses, these provide the basis for anecdotal elaboration of some of the aggregate survey results reported.

Table 1 reports the characteristics of the population of batik companies and those from which questionnaire returns were obtained. Response rates were lower in both districts in Surakarta as a reflection of the survey fatigue and now predominantly retail complexion of the industry. A total of 89 businesses completed questionnaires from a known total of 126 businesses involved in production giving an overall response rate of 71 per cent. Despite a measure of business turnover, working through batik industry leaders in each district, we were able to establish the total population of businesses with at least some production of batik with a good degree of accuracy. Table 1 indicates that the large majority of businesses that we surveyed could be classed as either juragan or saudagar producers. This was especially the case in Solo's Laweyan district—an historic centre of large-scale batik production. However, the opposite is now true of Kauman in the same city which is almost entirely populated by shops and, partly as a result, bakul traders. Three of the four districts surveyed had businesses of roughly the same mean age (of between 20 to 23 years) as at the point of survey in 2015. The businesses of the Kauman district of Surakarta were on average 10 years younger than those in the Laweyan 
district in the same city of Surakarta and younger on average also than those in both districts in Pekalongan, though an analysis of variance test suggests these differences were not statistically significant. Indeed the small number of businesses we were able to survey in the Kauman district of Surakarta means that differences in the ages of businesses aggregated to the city scale become negligible. ${ }^{5}$ The younger average age of businesses operating in the Kauman district of Surakarta likely reflects the re-birth of this centrally-located district as a grouping of retail showrooms.

The mean number of direct employees of the businesses surveyed across all four districts was under 10. Many of the older established businesses had reported declines in direct employment but in many cases had shifted to subcontracting to other companies or to outworkers. Indeed, at 23.3 outworkers per business on average, the businesses across all four urban districts actually employed more people indirectly. In fact, as several interviewees indicated, the total numbers of outworkers engaged is higher than these figures suggest since these outworkers, in turn, put out work to others. There are some differences in the organization of production across the four districts with those in Pesindon in Pekalongan and Kauman in Surakarta most oriented to the putting-out of production, though an analysis of variance test suggests that differences across the districts and across the cities are not statistically significant. ${ }^{6}$

\section{The batik industry in Surakarta and Pekalongan}

The precise origins of the batik technique are debated, though it appears that it was one imported to Indonesia (Elliot, 1984). Within Indonesia, the technique and traditional designs began to be 
developed on a significant scale first in north coast cities of Central and East Java such as Pekalongan and Cirebon and for the inland royal courts of Surakarta and Yogyakarta of Central Java. With the development of copper stamp technology by the middle to late 1800s, the industry became both fully commercial and urban in character.

In Surakarta, the district of Laweyan emerged in the 1800s as a more commerciallyoriented competitor to the traditional batiks produced for royalty in Kauman. Both the Kauman and Laweyan districts of Surakarta were home to substantial industrial agglomerations in which medium to large enterprises employed workforces drawn from the immediate vicinities. However, production in both urban districts has declined markedly. Where Laweyan was reportedly the largest batik producing district in Indonesia with at least 250 companies and 30,000 employees in the 1930s, to our knowledge there are no more than 30 Laweyan companies actively producing batik today, with those surveyed employing in the order of 500 workers directly. Pekalongan also has a long tradition of batik production but, as a coastal city at some distance from the seat of the Mataram Sultanate, its industrialists and merchants pioneered commercial batik production drawing on the designs and colours found in textiles traded from overseas. The city also offers a larger diversified production economy that includes a textile weaving industry (Sandee et al., 2002). Although known for batik, batik is part of a wider textiles agglomeration that employed around 130000 people in 2002 (Sandee et al., 2002).

Given these contrasting histories and orientations of batik production, our research was designed to detect any inter-urban and intra-urban contrasts to be found in the fortunes of batik 
companies. The fact that the results fail to indicate any such place-based differences in growth dynamics reflects both the strong commonalities across a traditional industry and the dissolution of these traditional, craft-based, industrial agglomerations. In both Surakarta and Pekalongan much of the remaining production activities (dying, wax outlines) now takes place outside the cities. Today, the main batik districts within each city are largely given over to showrooms, shops, restaurants and guesthouses_almost entirely so in Kauman in Surakarta.

Growth and growth constraints in the batik industry

Entrepreneurs were asked to indicate whether the turnover of their business had increased, remained stable or declined over the past five years (2009-2014/2015). As the results in Table 2 reveal, two-thirds of businesses across the four districts had experienced increases in turnover with only a minority experiencing declines. This is encouraging given that some of the industry districts have undergone significant decline in the past decades for several interrelated reasons. First, the districts surveyed are unlikely to be reborn or expanded significantly as production districts given the stricter planning and pollution controls enacted and enforced within both cities. Second, the mechanized printing of batik designs onto fabrics (not regarded as authentic batik) has nevertheless undercut the traditional and labour intensive techniques of hand drawing and stamping. Third, brokers or agents have undermined some of the autonomy of producers (Elliot, 1984) while three large vertically integrated companies—Danar Hadi, Batik Keris and Batik Semar-have emerged from the 1980s to dominate much of the local labour market in Surakarta and its hinterland. Taken together, these processes have resulted in what could be 
described (especially in the case of Surakarta) as the dissolution of urban industrial agglomeration and the emergence of a more geographically dispersed pattern of industrial organization based on the extensive use of outworkers.

The differences in the fortunes of the batik industry at the level of our two cities were negligible. In Surakarta, the Kauman district is both more centrally located and retail and tourism oriented than Laweyan and this may reflect the difficulties faced by producers rather than retailers and other activities, though the small numbers of observations preclude strong conclusions here. The Kauman district in Pekalongan also appears to have enjoyed better performance than the Pesindon district in the same city. Yet, a chi-squared test (where results for declines and stability in growth in Table 2 are collapsed) reveals that there are no statistical differences between districts in either of the two cities nor between the two cities.

Similarly, while the smaller bakul traders across all four districts in both cities appeared to be fairing better than their larger juragan and saudagar counterpart producers, the differences here are not statistically significant as measured by a chi-squared test (based on a two by two contingency table produced by collapsing the stable and declining categories).

Respondents were asked to list up to three main constraints on the development of their business and these were subsequently coded. The results in Figure 2 are aggregated at the level of the two cities (due to the small numbers of observations at the level of individual districts) and the two types of producers (juragan/saudagar and bakul) where small numbers are also apparent 
with respect to the latter type of business. The results in Table 3 should also be treated with caution due to the difficulties of coding some of the responses. They can provide some indication of the range of constraints facing batik businesses as a whole but provide nothing other than the most basic of guides to any contrasts that may exist at the scale of the two cities or between types of producers. For example, little can be said about contrasts here beyond the readily understandable greater concern among the juragan/saudagar producers for the availability and price of workers and raw materials when compared to their smaller bakul trader counterparts.

First, in line with many other surveys of small businesses regardless of societal context, capitalization or availability of capital stand out overall as the most important constraint on business development in the batik industry—identified by 30 per cent of businesses. The figure rises to 40 per cent if one includes an additional eight constraints identified under headings such as 'slow or late receipt of payment' included in the 'other' category.

Second, the availability and price of raw materials stands out as the second most important constraint on business development. There are a number of contributory factors here. There has been the gradual dismantling of the institutional support and protection that had developed historically around the batik industry. ${ }^{7}$ (Interview, GKBI representative, pers. comm., Surakarta, 9 September 2015). Shortages of mori-the cotton textile base from which much batik is made-were reported. This includes in Pekalongan where, although some interviewees indicated that sourcing was easier due to the presence of the nearby Primatex factory producing it (Bella Batik, pers. comm., Kauman, Pekalongan, 6 January 2015), others noted difficulties 
(Batik Griya, pers. comm., Kauman, Pekalongan, 5 January 2015) partly due to the fact that the factory produced mainly for export (Batik Nulaba, pers. comm., Kauman, Pekalongan, 5 January 2015).

Third, the availability of skilled workers emerged as an important constraint on the development of the industry and was a topic of conversation at almost every interview with batik entrepreneurs and with industry leaders (Interview, Industry Leader, pers. comm., Laweyan, Surakarta, 16 November 2014). Problems exist with recruiting enough well skilled young people into the industry (including sons and daughters as future company owners) given the growth of job opportunities in other manufacturing and service sectors in major cities and the poor working conditions common in the batik industry. The problems appear particularly severe in Surakarta where batik production has now more or less vacated Laweyan and Kauman. In Pekalongan there exists a larger urban labour market related to textiles and larger and more developed institutions dedicated to the training of batik workers (such as the polytechnic) as well as a museum and collective markets. Nevertheless, here too, the shortage of skilled labour also results in problems of poaching (Batik Seni, pers. comm., Kauman, Pekalongan, 6 January 2015).

Fourth, competition—including the impact of printing on the batik industry as well as imports including from China—was cited as an important constraint on business development. One interviewee indicated that the rise of Danar Hadi and Batik Keris as large vertically integrated batik businesses owed much to their being officially sanctioned as the faces of traditional batik designs and skills and modern techniques (i.e. printing) respectively under the 
Suharto regime (Interview, GKBI representative, pers. comm., Surakarta, 9 September 2015). Yet just as significant is the fact that these few larger companies continue to buy large volumes of batik from smaller independent producers to market under their own labels (Batik Qonita, pers. comm, Pekalongan, 8 January 2015; Widhiarto, pers. comm., Laweyan, Surakarta, 15 November 2014; Batik Seni, pers. comm., Kauman, Pekalongan, 6 January 2015; Batik Rizka, pers. comm., Kauman, Pekalongan, 6 January 2015). ${ }^{8}$

Fifth, the location and condition of premises was a concern for around a fifth of those surveyed. Apart from the often poor condition of buildings, these concerns are also a reference to the possibilities for showrooms and shops to be added to often small scale production facilities. Sixth, the weather and natural environment emerged as constraints cited by businesses which refers to the impact of sunlight on the stability and colour achieved in the dying process.

Forms of business change in the batik industry

Figure 3 reports on the forms of business change that entrepreneurs would like to pursue over the next five years. Respondents were asked to select from categories derived from Turok (1989) discussed in the literature above as well as being allowed to specify alternatives. Multiple responses were allowed and in a number of cases were given meaning that the percentages reported in Figure 3 sum to more than 100. There are three general conclusions that can be drawn from Figure 3. 
First, the majority of the batik enterprises surveyed had modest ambitions amounting to 'capital widening' — adding more of the same production capacity, making incremental changes to production techniques or making no change—rather than 'capital deepening'. Together these three forms of change accounted for over 50 per cent of changes reported by respondents. The focus of batik businesses in our survey was often on innovations that would save costs in production by finding cheaper sources of fuel for heating wax (Batik Mahkota, pers. comm., Laweyan, Surakarta, 16 November 2014; Ogut Batik, pers. comm., Laweyan, Surakarta, 15 November 2014) or having better research on natural dyes (Batik Mahkota, pers. comm., Laweyan, Surakarta, 16 November 2014). Here we find evidence of innovatory processes which rarely threaten the existence of the agglomeration itself, and instead more likely present as possible, elements of a survivalist strategy in response to falling profits (Turner, 2003: 172). Indeed, the philosophy of 'manajemen berkah' (that 'god will take care of the business') described by one batik entrepreneur (Batik Nietz, pers. comm., Pesindon, Pekalongan 8 January 2015) provides a vivid picture of the context in which entrepreneurial aspirations across a subset of businesses must be seen.

Second, a smaller proportion (25 per cent) of businesses nevertheless indicated that they were seeking significant changes to their products or processes. Some batik producing companies described their desire to expand their marketing efforts by modernizing nonproduction activities with better use of computer and internet technologies to improve administration and sales and marketing (Batik Nietz, pers. comm., Pesindon, Pekalongan 8 
January 2015). Nevertheless, here, some of the limits of language (derived from the formal manufacturing sectors in developed countries) to convey meaning may have been reached. In particular, there have been few and infrequent developments in the process technologies associated with batik over several centuries. The original method of hand writing (canting) with small stoves heating beeswax and natural dyes was joined from the mid-1800s (Kitley, 1992) by the large scale use of hand-held copper stamps (cap) for imparting wax onto cloth. The use of stamps proved an effective response to cheap imports of printed batik from European nations and prompted the expansion of distinctly urban and male employment in the industry by the early 1900s. The use of synthetic dyes and the adoption of mechanical printing (without wax) of batik patterns onto material (not strictly batik) began from the 1960s. In the field, we were shown one printing process which the owner claimed could be considered batik since it used wax, though the commercial success of this technique will not be clear for some time (Batik Rizka, Kauman, Pekalongan 6 January 2015). In reality, the likely meaning of these aspirations relate to the introduction of new batik designs whether for hand or stamp. There is a vast and ancient repertoire of designs that batik producers can draw upon and combine. This calls into the question the significance and novelty of what this body of entrepreneurs may be describing, though for a few such significant changes to products may well represent significant change to the industry and the entrepreneur especially, where those designs are modern or abstract. Buyers or agents interlocute between western tastes and local production capabilities driving innovation in designs. Indeed, these tastes are twice mediated as a result of agents serving buyers through 
internationally accessible cities such as the capital Jakarta but also the likes of Yogyakarta and Bali, the latter's textile industry agglomerations having developed significantly (Hassler, 2005; Tambunan \& Wie, 2009).

Third, a small proportion of businesses indicated they were seeking diversification either within or out of the batik industry. However, the extent of this desire is not immediately obvious from Figure 3 because a large proportion of the 30 entrepreneurs indicating that they held 'other' aspirations for their business actually were describing a desire for various forms of downstream diversification. This has been one route-by the efforts of entrepreneurs themselves but also supported by government and NGOs-through which the vestiges of batik communities have been revived or preserved in Surakarta in particular. For example, 9 of the 35 were seeking to open a shop/showroom. Other common concerns were a desire to improve marketing of products (noted by 11 of the 35 and a desire to develop labour skills (noted by 6 of the 35) especially in the case of Surakarta.

The small numbers of observations in Figure 3 make it difficult to say much conclusively about different forms of growth pursued by businesses according to their location or segment. The batik industry in Pekalongan remains more buoyant than that in Solo and, as we noted above, historically has been more open to design influences from overseas and this may be one reason for the higher proportions of businesses there engaging in significant development of their batik products including new designs. There is some suggestion in the data that, proportionately, 
the bakul producers appear more inclined not to change their businesses when compared to the larger juragan and saudagar producers but the numbers of observations here are tiny.

Overall, the data presented in Figure 3 provide a mixed picture. On the one hand they appear to confirm the existence of past rigidities among entrepreneurs noted by one interviewee with an overview of the many smaller companies in the industry (Interview, Batik Keris, pers. comm., Surakarta, 10 September 2015). Nevertheless, the interviewees noted a greater versatility among younger entrepreneurs who had entered the industry while, historically, entrepreneurs have been extremely resourceful at times of crisis.

Policy, clustering and segmentation

A lack of government support and the small scale of the industry emerged specifically as constraints mentioned only five times (in the 'other' category) in the data in Figure 2. These findings are curious. To an extent they chime with the generalized satisfaction with the entrepreneurship ecosystem in Indonesia found in one recent survey (Nawangpalupi et al., 2014: 47-8) — though the same survey found that national regulations and government policies in Indonesia compared less favourably to other Asian countries. Moreover, Tambunan (2005) is critical of failures in policy approaches in Indonesia, including the effects of government policies to support clusters actually eroding capacities for self-organization.

Central Java is an intriguing laboratory in which to examine the impacts of policies to support 'joint action' (Schmitz, 1995, 1999) among businesses in the many industry 
agglomerations that exist there (Phelps \& Wijaya, 2016). While not informed explicitly by this concept, support for industry agglomerations and joint action across the province has been extensive. Almost every district has established a new institution-a FEDEP (Forum for Economic Development and Employment Promotion)—-the purpose of which is to galvanize such joint action most commonly around industry agglomerations. These FEDEPs have been active in steering strategic interventions from local and provincial government and other donors in the cases of batik industries in both Surakarta and Pekalongan. Moreover, both cities have a series of plans (ranging from 5 years to 20 years) that explicitly include support for the development of industry agglomerations in general and batik agglomerations in particular. ${ }^{9}$ Thus, following on from questions regarding the constraints on the development of batik businesses, we asked entrepreneurs for their perceptions of whether policies to support industry agglomerations will be able to resolve the sorts of constraints they face. Businesses were able to respond with a 'yes', 'no' or 'don't know' answer and here we calculate chi-squared statistics based on collapsing the 'no' and 'don't know' answers to produce simpler two by two contingency tables to test differences at the levels of the two cities or in terms of segmentation into juragan/saudagar and bakul businesses.

Data presented in Table 3 indicates that a majority of businesses in each district, in each city and overall believe that cluster policies could help address these constraints, though the results are not quite as unanimous in their affirmation of the value of such policy-led joint action as one might suppose since overall, a significant minority (41.9 per cent) of entrepreneurs either 
do not believe that cluster policies can help or were unsure. The result here should not be underestimated since clusters have been the explicit focus of support from provincial government and in both cities—a fact that might be expected to draw uncritical commentary from businesses with a vested interest in receiving support. In the case of craft industries in Nairobi, Harris (2016) reports how the institutional context presents asymmetric rent-seeking opportunities for some firms, those individuals or institutions managing industry agglomerations and for government officials. Though similar, such concerns also undoubtedly surround joint action activities centered on the batik clusters considered here-we do not have evidence in this study for a strong version of these claims.

Nevertheless, Harris' (2016) broader suggestion that informality may present limits upon policy, mobilizing the higher order forms of joint action associated with significant innovation and particular forms of business growth, is important. There are a number of factors contributing to the efficacy of new institutions surrounding batik industry agglomerations in Surakarta and Pekalongan and the joint action they may be able to generate, as we have reported (Phelps \& Wijaya, 2016). Of particular importance is the fact that efforts to promote such joint action can sit uncomfortably with the extant and historical organization of the industry, which is often segmented into a limited number of leading companies with their own histories, traditions and retained workers and numerous subcontractors and outworkers.

Chi-squared tests revealed no statistically significant differences between perceptions of businesses in districts in either Surakarta or Pekalongan with regard to the likely efficacy of 
cluster policies. In the case of data for Surakarta, the responses of businesses were unambiguously optimistic for the prospects of policy to assist joint action, though there is a minor contrast in perceptions evident among businesses in the two districts. This is perhaps not surprising given the younger average age of the companies surveyed in Kauman compared to Laweyan and given that the focus of cluster support in the city shifted some years ago from Laweyan to Kauman with business leaders in Laweyan critical of local government vis a vis the support of other agencies (Phelps \& Wijaya, 2016) though local government attention has also since switched from both batik clusters to one centred on waste paper (Interview, Bappeda (local government planning board) representative, pers. comm., Surakarta, 14 November 2014).

A chi-squared test does reveal statistically significant differences in perceptions of businesses once results are aggregated to the city scale $\left(\chi^{2}=6.82, \mathrm{p}<0.95 \%\right)$ with respondents in Surakarta, on balance, more optimistic regarding the likely effects of policy and respondents on balance, less optimistic in Pekalongan. Here it may be that Surakarta's reputation as a model of public policy innovation and regulatory reform within Indonesia (Phelps et al., 2014) is warranted, though it should be noted that Pekalongan is home to several important new institutions_-a major market, a polytechnic and a museum—oriented to batik.

Finally, across the districts in both cities, although a higher proportion of the smaller bakul businesses perceived that policy in support of industry agglomerations had had a positive effect than was the case for the larger juragan/saudagar businesses, these differences are not 
statistically significant. The results are expected here in that it is likely to be smaller businesses that are in most need of, and which stand to benefit most from, such policy interventions.

\section{Conclusion}

The fact that only a third of businesses surveyed had experienced stagnation or decline and that the constraints upon business growth identified were, in the main, external to business, paints a reasonably positive picture of small firm growth prospects in the batik industry in Indonesia. Business optimism and opportunities may have increased from a recent low point of the 1990s. Yet these findings are tempered by the internal constraints on business development implied in the forms of change typically being sought by batik businesses. Here, assumptions regarding the widespread presence of Schumpeterian entrepreneurialism that might drive the fuller exploitation of latent external economies appear unwarranted. Despite the superficial similarities between craft industry agglomerations in developing counties and those in the Third Italy, the findings presented here point to the need to further specify the connections between individual and collective dynamics as these produce a variegated landscape of industry agglomeration across developed and developing countries.

In this latter regard, the notion of segmentation has a value that is not limited to better specifying agglomeration processes in the developing country setting, but to the further development of agglomeration theory in the round. Some important aspects of such ‘segmentation’ of industry agglomerations (Taylor \& Thrift, 1982) are manifested in, and can be 
analysed in terms of, variable aspirations of business people, the constraints they face in developing their businesses and in the forms of business growth and change that they pursue. If segmentation appears as an important policy-redolent concept to both developed and developing countries (Nichter \& Goldmark, 2009: 1461), our exploratory analysis revealed no statistically significant differences between the two segments of small-scale bakul traders and the mediumscale juragan and saudagar merchant producers. Future investigations may need to explore other dimensions of segmentation. For example, such segmentation has existed historically along ethnic, religious and political lines in Solo’s Laweyan district, though we are unable to explore these dimensions here.

Finally, our findings also reopen thorny issues for policy for supporting the small firm sector and industry agglomerations. Our findings—of an absence of any differences in growth and growth constraints facing individual businesses and effects of policy toward industry agglomerations — tend to confirm a lack of critical mass of businesses and hence the absence of meaningful batik agglomerations in these cities (see also Phelps \& Wijaya, 2016). In light of this, should efforts to support businesses be concentrated on the most dynamic? Should policy be focused on those businesses with the greatest growth aspirations which are also in any case likely to be those that are self-selecting in terms of seeking the benefits of joint action (of business support and business networking) and the pursuit of 'modern' intensive forms of growth? Even among these most dynamic businesses, there might be further scope for concentrating resources on those pursuing particular types of growth-notably those forms of growth most scarce in the 
developing country context—product development, technological change and diversification. Such questions are uncomfortable ones especially in light of the continuing need for economic growth and development to drive broad-based poverty alleviation across the global south.

\section{Acknowledgements}

The authors would like to thank the editor and referees for their comments on a previous draft of this paper and the National Geographic Global Exploration Fund (GEFNE106-14) for funding the research on which this paper is based.

\section{Endnotes}

1 In his discussion of the possibilities for joint action, Schmitz (1999: 478) is careful to note that Schumpeterian entrepreneurial forces are limited in the developing country setting.

2 Many of the businesses located in each of these districts had changed from being involved with production to being involved in sales and the coordination of production carried out by outworkers and subcontractors (Handayani et al., 2013).

3 For example, a postgraduate student from an Indonesian university was surveying the same businesses at the same time as us in Laweyan. A doctoral student had completed a survey of businesses in Laweyan and Kauman a year prior to our survey (Handayani et al., 2013), while local NGO Kota Kita had also surveyed local residents in the years preceding.

4 The peak association organization for batik cooperatives in Indonesia. 
5 Indeed, the statistical significance $(\mathrm{p}=.96)$ of an $\mathrm{F}$ score of 0.003 even suggests the opposite — that the businesses are, with a mean business age of 20.47 in Surakarta and 20.55 in Pekalongan, effectively part of the same population.

6 An analysis of variance test across the four districts gives rise to an F score of 1.714 $(\mathrm{p}=.171)$. The same test across the two cities gives an F score of $0.097(\mathrm{p}=.756)$.

7 As early as the 1930s, and at the height of the industry in places like Surakarta, the Dutch administration even sought to provide a measure of protection for the industry and its traditions. Both Islamic and Communist strands of resistance to Dutch rule had fed into a comprehensive system of collective organization surrounding the batik industry by the 1960s under Sukarno's Presidency involving compulsory membership of the national batik producers' association and cooperative control of the production and distribution of cotton fabric and dyes (Brenner, 1998).

8 The few large companies include Javanese Batik Danar Hadi (originating from the 1960s) and Batik Keris and Batik Semar originating from the same Chinese-Indonesian family in the 1940s in Surakarta and Batik Qonita which has emerged in the 1990s as the largest single company in Pekalongan.

9 Surakarta's City Long Term Development Plan (2005-2025 Regulation No.2/2010), City Strategic Development Plan (2016-2021) each make mention of supporting increasing medium and small and medium enterprise agglomerations while Regulation 9/2016 and 
Mayor Instructions 534.05/136-B/1/2004 and 500.05/01/1/2013 have supported batik agglomerations in Laweyan and Kauman. Likewise, Pekalongan's City Long Term Development Plan and Strategic Development Plan include notable mentions of support for industry agglomerations while Regulation no.6/2014 and Mayor Regulations nos. 27/2018 and 17A/2015 provide specific support for the batik industry in the city.

\section{References}

Advisory Council on Science and Technology (ACOST) (1990) The Enterprise Challenge: Overcoming Barriers to growth in Small Firms. HMSO, London.

Altenburg T, Meyer-Stamer J (1999) How to promote clusters: policy experiences from Latin America. World Development 27, 1693-713.

Bosma N, Schutjens VAJM (2009) Determinants of early-stage entrepreneurial activity in European regions: distinguishing high and low ambition entrepreneurship. In Smallbone D, Landström H, Jones-Evans D (eds) Entrepreneurship and Growth in Local, Regional and National Economies: Frontiers in European Entrepreneurship Research, 49-79. Edward Elgar, Cheltenham.

Brenner SA (1998) The Domestication of Desire: Women, Wealth, and Modernity in Java. Princeton University Press, Princeton.

Davidsson P (1991) Continued entrepreneurship: ability, need and opportunity as determinants of small firm growth. Journal of Business Venturing 6, 405-29. 
Dicken P, Hassler M (2000) Organizing the Indonesian clothing industry in the global economy: the role of business networks. Environment \& Planning A 32, 263-80.

Elliot IM (1984) Batik: Fabled Cloth of Java. Clark Potter, New York.

Gesellschaft für Technische Zusammenarbeit (GTZ) (2008) Rattan Furniture Value Chain Promotion In the Solo Region, Central Java Indonesia. GTZ, Jakarta.

Gordon I, McCann P (2000) Industrial clusters: complexes, agglomeration and/or social networks. Urban Studies 37, 513-32.

Handayani KN, Sakai T, Deguchi A, Divigalpitiya P (2013) Features and issues of urban batik cluster development in Surakarta and Yogyakarta, Indonesia. Journal of Architecture and Planning 78 (696), 837-46.

Harris J (2016) Joint action in Nairobi’s informal handicraft industry clusters. International Development Planning Review 38, 317-37.

Hassler M (2005) Global markets, local home-working: governance and inter-firm relations in the Balinese clothing industry. Geografiska Annaler B 87, 31-43.

Japan International Cooperation Agency (JICA) (2004) The Study on Strengthening Capacity of SME Clusters in Indonesia. Japan International Cooperation Agency, Tokyo.

Kitley P (1992) Ornamentation and originality: involution in Javanese batik. Indonesia 53, 1-19

McGee T (1974) The persistence of the proto-proletariat: occupational structures and planning for the future of the third world city. Paper presented at the Comparative Urban Studies Conference. Urban Planning Programme, UCLA, Los Angeles.

Massey D, Meegan R (1983) An Anatomy of Job Loss. Methuen, London. 
Moreno-Monroy A (2012) Informality in space: understanding agglomeration economies during economic development. Urban Studies 49, 2019-30.

Nadvi K (1999) Collective efficiency and collective failure: the response of the Sialkot surgical instrument cluster to global quality pressures. World Development 27, 1605-26.

Nawangpalupi CB, Pawitan G, Gunawan A, Widyarini M, Bisowarno BH, Iskandarsjah T (2014) Global Entrepreneurship Monitor 2014, Indonesia Report. UNPAR Press, Bandung.

Nichter S, Goldmark L (2009) Small firm growth in developing countries. World Development 37, 1453-64.

Oakey RP (1983) Innovation and regional growth in small high technology firms: evidence from Britain and the USA. Regional Studies 18, 237-51.

O'Farrell PN, Hitchens DMWN (1988) Alternative theories of small firm growth: a critical review. Environment and Planning A 20, 1365-83.

Perry M (2005) Business clusters in the south: A critical appraisal from Indonesian evidence. Singapore Journal of Tropical Geography 26, 227-43.

Phelps NA (1992) External economies, agglomeration and flexible accumulation. Transactions of the Institute of British Geographers 17, 35-46.

Phelps NA, Bunnell T, Miller M, Taylor J (2014) Urban inter-referencing within and beyond Indonesia. Cities 39, 37-49.

Phelps NA, Wijaya H (2016) Joint action in action? Local economic development forums and industry cluster development in Central Java, Indonesia. International Development Planning Review 38, 425-48. 
Small Business Research Centre (1992) The State of British Enterprise: Growth, Innovation and Competitive Advantage in Small and Medium-Sized Firms. Small Business Research Centre, Cambridge.

Sandee H, Isdijoso B, Sulandjari S (2002) SME Clusters in Indonesia: An Analysis of Growth Dynamics and Employment Conditions. International Labour Office, Geneva.

Schmitz H (1982) Growth constraints on small-scale manufacturing in developing countries: a critical review. World Development 10, 429-50.

Schmitz H (1995) Collective efficiency: growth path for small scale industry. Journal of Development Studies 31, 529-66.

Schmitz H (1999) Collective efficiency and increasing returns. Cambridge Journal of Economics 23, 465-83.

Storey DJ (1994) Understanding the Small Business Sector. Routledge, London.

Tambunan T (2005) Promoting small and medium enterprises with a cluster approach: a policy experience from Indonesia. Journal of Small Business Management 43, 138-54.

Tambunan T, Wie TK (2009) Technology/Knowledge transfer and diffusion in Indonesian nonfarm enterprises. In McCulloch N (ed) Rural Investment Climate in Indonesia 140-91. Institute of Southeast Asian Studies, Singapore.

Taylor M, Thrift N (1982) Industrial linkage and the segmented economy 1: some theoretical proposals. Environment and Planning A 14, 1601-13.

Turner S (2003) Indonesia’s Small Entrepreneurs: Trading on the Margins. Routledge-Curzon, London. 
Turok I (1989) Evaluation and understanding in Local economic policy. Urban Studies 26, 587606.

Weijland H (1999) Microenterprise clusters in rural Indonesia: Industrial seedbed and policy target. World Development 27, 1515-30.

Van der Kroef JM (1960) The Indonesian entrepreneur: images, potentialities and problems. American Journal of Economics and Sociology 19, 413-25.

Wijaya M (2009) Multi-commercial economy: the development of socio-economic network complexity of batik industry in Surakarta. Asian Social Science 5, 102-10.

\section{Figures}

Figure 1. Batik Kampong study areas in Surakarta and Pekalongan

Source: Map data (C) OpenStreetMap contributors. CC-BY-SA. opendatacommons.org

Figure 2. Main constraints on business development.

Source: Author's survey.

Figure 3. Forms of business change being sought by batik producers over the next five years (\%)

Source: Author's survey.

Tables

Table 1. Summary details of population and surveyed batik producing companies

\begin{tabular}{|l|c|c|c|c|c|}
\hline \multirow{2}{*}{} & \multicolumn{2}{|c|}{ Surakarta } & \multicolumn{2}{c|}{ Pekalongan } & \multirow{2}{*}{ Total } \\
\cline { 2 - 4 } & Kauman & Laweyan & Kauman & Pesindon & \\
\hline
\end{tabular}




\begin{tabular}{|l|l|l|l|l|l|}
\hline $\begin{array}{l}\text { Total population of } \\
\text { batik producing } \\
\text { businesses }\end{array}$ & 24 & 35 & 37 & 30 & 126 \\
\hline $\begin{array}{l}\text { Number surveyed } \\
\text { (response rate) }\end{array}$ & $11(45.8 \%)$ & $22(62.9 \%)$ & $32(86.5 \%)$ & $24(80.0 \%)$ & $89(70.6 \%)$ \\
\hline $\begin{array}{l}\text { Number and } \\
\text { percentage of } \\
\text { Juragan/Saudagar } \\
\text { respondents }\end{array}$ & $5(45.5 \%)$ & $21(95.5 \%)$ & $22(68.8 \%)$ & $16(66.7 \%)$ & $64(74.4 \%)$ \\
\hline $\begin{array}{l}\text { Direct employment } \\
\text { (as a percentage of } \\
\text { total employment) }\end{array}$ & $162(29.8 \%)$ & $544(39.0 \%)$ & $135(60.2 \%)$ & $24(3.0 \%)$ & $865(29.4 \%)$ \\
\hline $\begin{array}{l}\text { Outworkers (as a } \\
\text { percentage of total } \\
\text { employment) }\end{array}$ & $382(70.2 \%)$ & $850(61.0 \%)$ & $89(39.8 \%)$ & $755(97.0 \%)$ & $2076(70.6 \%)$ \\
\hline $\begin{array}{l}\text { Total employment } \\
\text { Average age of } \\
\text { business (Years) }\end{array}$ & 544 & 1394 & 224 & 779 & 2941 \\
\hline
\end{tabular}

Source: Author's survey.

Table 2. Change in turnover of batik production businesses in the last five years

\begin{tabular}{|l|c|c|c|c|c|c|c|c|}
\hline \multirow{2}{*}{} & \multicolumn{2}{|c|}{ Surakarta } & \multicolumn{2}{c|}{ Pekalongan } & \multicolumn{2}{c|}{ Producers } & \multicolumn{2}{c|}{ Total } \\
\cline { 2 - 9 } & Kauman & Laweyan & Kauman & Pesindon & Juragan/Saudagar & Bakul & Surakarta & Pekalongan \\
\hline Grown & $9(81.8 \%)$ & $12(54.5 \%)$ & $22(71.0 \%)$ & $13(59.0 \%)$ & $31(50.8 \%)$ & $14(56.0 \%)$ & $21(63.6 \%)$ & $35(66.0 \%)$ \\
\hline Stable & $2(18.2 \%)$ & $6(27.3 \%)$ & $8(25.8 \%)$ & $4(18.2 \%)$ & $24(39.3 \% \%)$ & $9(36.0 \%)$ & $8(24.2 \%)$ & $12(22.6 \%)$ \\
\hline Declined & $0(0.0 \%)$ & $4(18.2 \%)$ & $1(3.2 \%)$ & $5(22.7 \%)$ & $6(9.8 \%)$ & $2(8.0 \%)$ & $4(12.1 \%)$ & $6(11.3 \%)$ \\
\hline & $\mathrm{N}=11$ & $\mathrm{~N}=22$ & $\mathrm{~N}=31$ & $\mathrm{~N}=22$ & $\mathrm{~N}=61$ & $\mathrm{~N}=25$ & $\mathrm{~N}=33$ & $\mathrm{~N}=53$ \\
\cline { 2 - 8 } & \multicolumn{2}{|c|}{$\chi^{2}=2.36$} & \multicolumn{2}{c|}{$\chi^{2}=0.81$} & $\chi^{2}=0.19$ & \multicolumn{2}{c|}{$\chi^{2}=0.52$} \\
\hline
\end{tabular}

Source: Author's survey.

Table 3. Business perceptions of whether cluster policies can resolve constraints on business growth

\begin{tabular}{|l|c|c|c|c|c|c|c|c|}
\hline & \multicolumn{2}{|c|}{ Surakarta } & \multicolumn{2}{c|}{ Pekalongan } & \multicolumn{2}{c|}{ Total } & \multicolumn{2}{c|}{ Total } \\
\cline { 2 - 8 } & Kauman & Laweyan & Kauman & Pesindon & $\begin{array}{c}\text { Juragan/Sau } \\
\text { dagar }\end{array}$ & Bakul & Surakarta & Pekalongan \\
\hline Yes & $10(90.9 \%)$ & $15(68.2 \%)$ & $15(50.0 \%)$ & $10(43.5 \%)$ & $35(56.5 \%)$ & $15(62.5 \%)$ & $25(75.8 \%)$ & $25(47.2 \%)$ \\
\hline
\end{tabular}




\begin{tabular}{|l|l|l|l|l|l|l|l|l|}
\hline No & $1(9.1 \%)$ & $6(27.3 \%)$ & $6(20.0 \%)$ & $9(39.1 \%)$ & $14(22.6 \%)$ & $7(29.2 \%)$ & $7(21.2 \%)$ & $15(28.3 \%$ \\
\hline $\begin{array}{l}\text { Don't } \\
\text { know }\end{array}$ & $0(0.0 \%)$ & $1(4.5 \%)$ & $9(30.0 \%)$ & $4(17.4 \%$ & $13(21.0 \%)$ & $2(8.3 \%)$ & $1(3.0 \%)$ & $13(24.5 \%)$ \\
\hline & $\mathrm{N}=11$ & $\mathrm{~N}=22$ & $\mathrm{~N}=30$ & $\mathrm{~N}=23$ & $\mathrm{~N}=62$ & $\mathrm{~N}=24$ & 33 & 53 \\
\cline { 2 - 9 } & \multicolumn{2}{|c|}{$\chi^{2}=2.06$} & \multicolumn{2}{c|}{$\chi^{2}=0.22$} & $\chi^{2}=0.26$ & $\chi^{2}=6.82, \mathrm{p}<0.95$ \\
\hline
\end{tabular}

Source: Author's survey. 
Figure 1 Batik Kampong study areas in Surakarta and Pekalongan

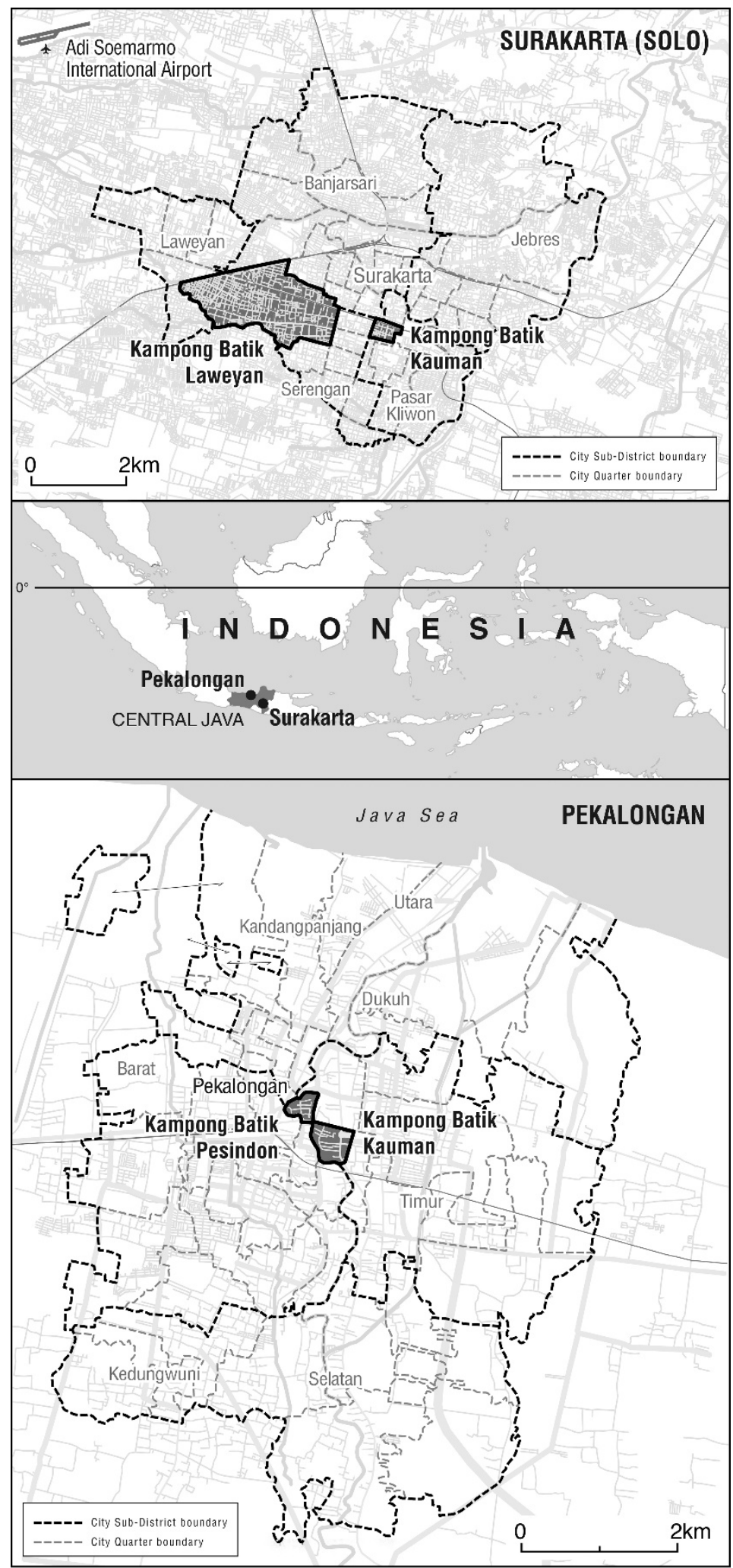

Map data $\odot$ OpenStreetMap contributors, CC-BY-SA, opendatacommons.org

This article is protected by copyright. All rights reserved. 
Figure 2 Main constraints on business development

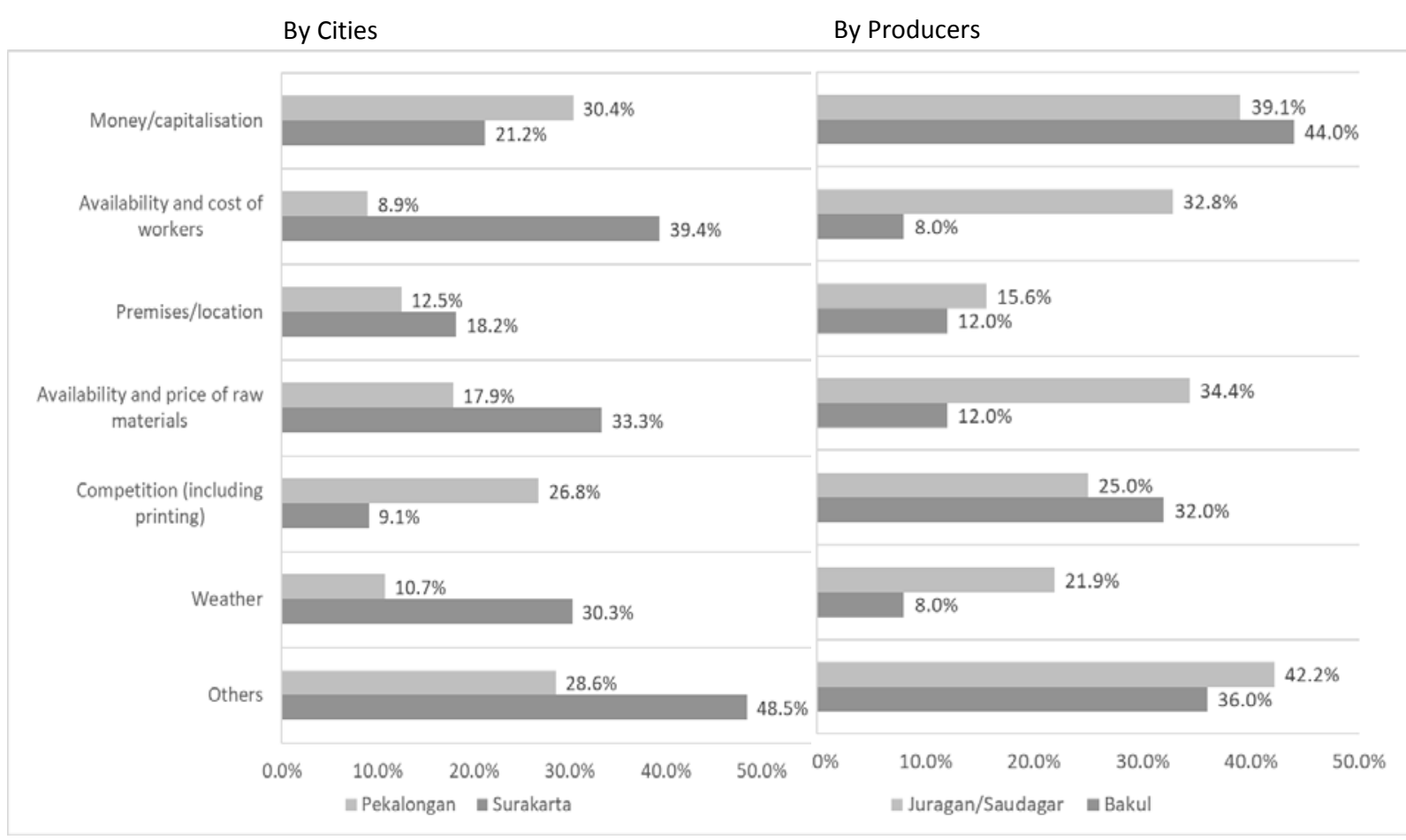

This article is protected by copyright. All rights reserved. 
Figure 3 Forms of business change being sought be batik producers over the next five years (\%)

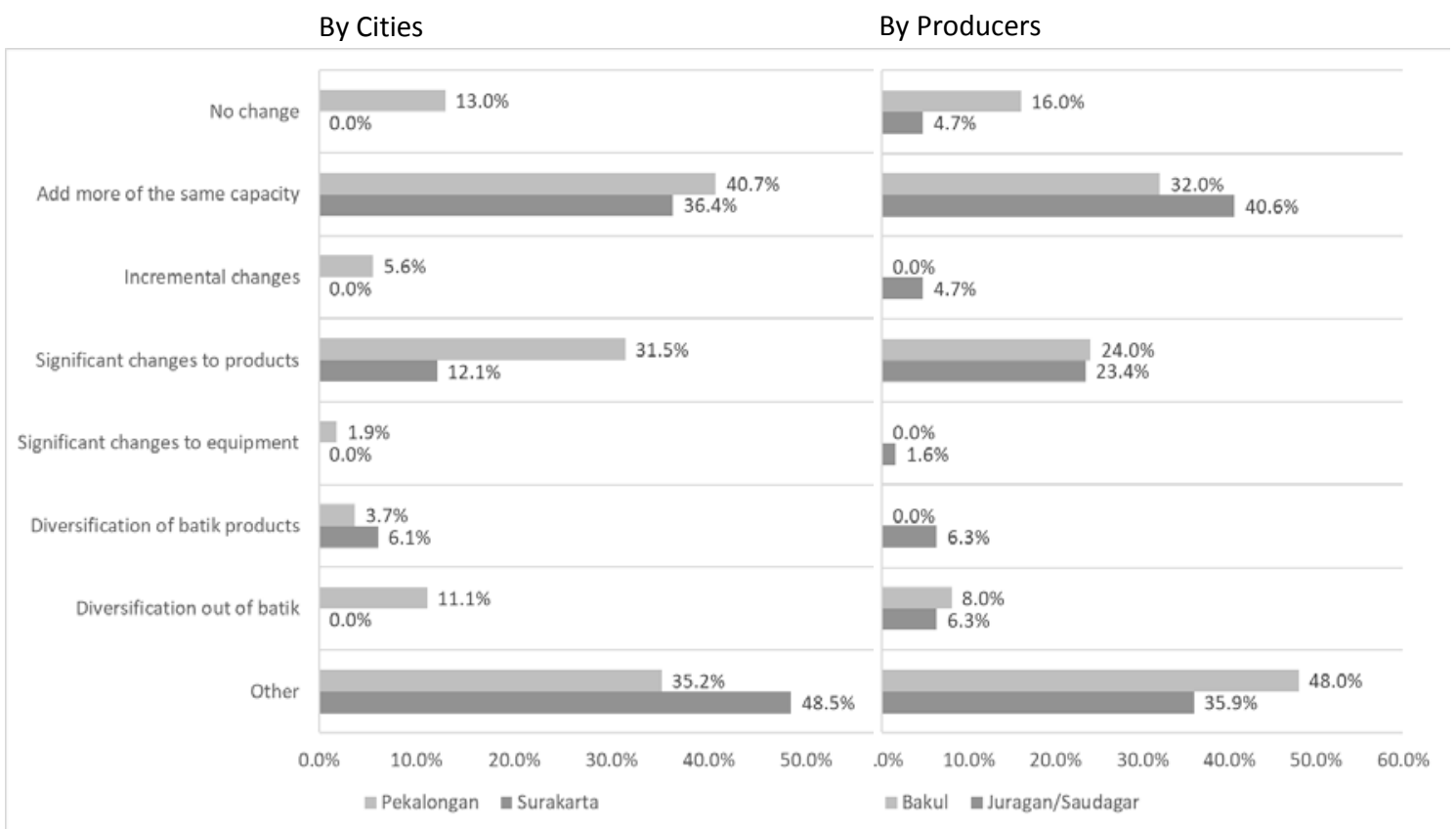

This article is protected by copyright. All rights reserved. 


\section{University Library}

\section{- M M N E R VA A gateway to Melbourne's research publications}

Minerva Access is the Institutional Repository of The University of Melbourne

Author/s:

Phelps, NA;Wijaya, HB

Title:

Growth and growth constraints in craft industry clusters: The batik industries of Central Java

Date:

2020-02-03

Citation:

Phelps, N. A. \& Wijaya, H. B. (2020). Growth and growth constraints in craft industry clusters: The batik industries of Central Java. SINGAPORE JOURNAL OF TROPICAL GEOGRAPHY, 41 (2), pp.248-268. https://doi.org/10.1111/sjtg.12311.

Persistent Link:

http://hdl.handle.net/11343/276830 